\title{
KONSTRUKSI AGRILITERACY MELALUI DONGENG “DEWI SRI”
}

\author{
Lilik Wahyuni \\ Universitas Brawijaya \\ Lilikwahyuni.bi@gmail.com
}

Diterima: 31 Desember 2018

Publikasi: 27 Februari 2019

DOI: http://dx.doi.org/10.32528/bb.v4i1.1869

\begin{abstract}
ABSTRAK
Pendidikan merupakan proses internalisasi nilai-nilai menjadi jati diri pembelajaragar melahirkan kesadaran kritis terhadap budaya lokal, salah satunya dunia agraris (agriliteracy). Agar menyenangkan, internalisasi nilai di Fakultas Pertanian dilakukan melalui matakuliah Bahasa Indonesia dengan media dongeng.Penelitian ini menggunakan pendekatan kualitatif deskriptif dengan metode analisis isi kualitatif.Sumber data penelitian ini adalah dongeng "Dewi Sri" dengan menggunakan teknik dokumentasi, observasi, dan studi pustaka sebagai pengumpul data.Penelitian ini bertujuan untuk mendapatkan eksplanasi tentang (1) pesan dan (2) peran dongeng "Dewi Sri" sebagai pembangkit imajinasi agriliterasi mahasiswa. Hasil penelitian ini adalah (1) pesan dongeng "Dewi Sri" adalah Dewi Sri merepresentasikan tanah merupakan ibu yang "melahirkan" tanam-tanaman yang dibutuhkan oleh manusia. Mahasiswa sebagai anggota masyarakat agraris harus menghargai tanah sesuai dengan budaya agrarisnya agar terbentuk integritas dan rasa syukur dan (2) peran dongeng "Dewi Sri"adalah sebagai media yang ramah dan menyenangkan untuk meningkatkan kemampuan literasi ekologisebagai perekat keharmonisan hidup manusia dengan sesama dan alam yang menjadi tempat hidup dan kehidupan.
\end{abstract}

Kata Kunci: konstruksi, agriliteracy, dongeng "Dewi Sri”, Matakuliah Bahasa Indonesia, Fakultas Pertanian

\begin{abstract}
Education is a value internalization process into student identity to develop critical awareness on local culture, such as agrarian (agriliteracy). To make it more interesting, value internalization at School of Agriculture done through subject of Bahasa Indonesia with tale as its media. This research uses a qualitative descriptive approach with the method qualitative content analysis. Data resource in this research is the tale "Dewi Sri" using documentation, observation, and literature review method to collect data. The purpose of this research is to get the explanation of (1) message and (2) the role of the tale "Dewi Sri" as student's agriliteracy imagination trigger. The result of this research is (1) the message of "Dewi Sri" tale is that Dewi Sri, which represent soil, is the mother that "give birth" to plants needed by human. Student as a part of agrarian society have to value soil as their agrarian society culture to create a sense of integrity and gratitude and (2) the role of "Dewi Sri" tale as a sociable and fun media to improve ecological literacy skill as an adhesive of human life harmonic within each other and nature that becomes place to live and life.

Keyword: construction, Agriliteracy, "Dewi Sri" tale, Subject of Bahasa Indonesia, School of Agriculture
\end{abstract}




\section{PENDAHULUAN}

Pendidikan merupakan proses pengembangan jati diri pembelajar agar memiliki kemampuan mengkritisi nilainilai dasar budaya lokal serta memahami dunia. Melalui proses belajar, pendidikan melahirkan "kesadaran kritis" individual maupun kelompok yang dilakukan secara otonom, memanusiakan, dan memerdekakan. Pembelajaran tersebut didasari oleh konsep literasi sebagai proses penanaman metode berpikir kritis yang bermanfaat bagi pembangunan manusia (Freire dalam Kusumadewi, 2017).

Literasi merupakan proses belajar sepanjang masa agar pembelajar menjadi subjek, yaitu manusia yang berkarakter bijak, kritis, kreatif, dan peduli agar dapat bersimpati, berempati, dan berkompati (compathy) terhadap diri, sesama, serta lingkungan hidupnya (Freire dalam Kusumadewi, 2017). Dalam masyarakat agraris, proses literasi dilakukan institusi pendidikan agar pembelajar menjadi subjek agraris (agriliterasi). Karena itu, pembelajaran yang dilakukan tidak sekadar transfer pengetahuan dan keahlian fungsionalakan tetapi lebih pada praktik internalisasi nilai-nilai agraris agar terinternalisasimenjadi habitus pembelajar.

Salah satu institusi pendidikan yang diharapkan mampu membentuk habitus agraris adalah Fakultas Pertanian. Lulusan Fakultas Pertanian harus mampu menjadi manusia yang bijak, kritis, kreatif, dan peduli sehingga mereka dapat bersimpati, berempati, dan berkompati (compathy) terhadap diri, sesama, serta lingkungan hidup agraris. Mereka harus memiliki kemampuan mengeksplor masalah pendidikan dan pekerjaan sehingga mereka mampu menginternalisasi kemampuan diri dengan masalah pekerjaan yang meliputi perencanaan dan pengambilan keputusan dalam pemilihan pekerjaan. Sebagaimana dikatakan Rick (2002) bahwa materi pembelajaran yang berkaitan dengan pekerjaan menjadi panduan untuk memahami dan menerapkan konsep kerja pekerjaan yang berkelanjutan. Pembelajaran merupakan praktik memberikan ide-ide praktis tentang cara melakukan pekerjaan agar menjadi pengetahuan yang dapat digunakan dalam pengembangan dan perencanaan proyek pada skala yang berbeda. Dalam bidang pertanian, FAO dalam Oxenham (2002) mengatakan agar bisa berhasil, pengingkatan pertanian dengan teknologi baru harus dilakukan dengan pemaduan pelatihan dan literasi secara bersamaan.

Penanaman budaya agraris tidak bisa dilakukan melalui pembelajaran yang instan.Dalam diri anak harus dikonstruk imajinasi moral tentang budaya agraris agar mahasiswa tidak menjadi pribadi yang laissez faire, tetapi pribadi yang mampu mempertanggungjawabkan budaya agrarisnya. Imajinasi moral digunakan seseorang sebagai upaya agar mereka dapat melakukan tindakan yang benar untuk memutuskan suatu pilihan moral. Penalaran moral merupakan pertimbangan faktor-faktor yang relevan untuk membuat jenis penilaian yang 
dilakukan terhadap diri sendiri maupun orang lain. Sebagai suatu proses, imajinasi moral dapat dimanfaatkan, diolah, dan dikembangkannya. Semakin pandai dan kreatif seseorang memanfaatkan imajinasinya, akan semakin meningkat pemikiran, kebanggaan, dan kepuasan baik secara material maupun spiritual.

Peningkatan imajinasi moral bisa dilakukan melalui matakuliah bahasa Indonesia. Dalam RKPS Matakuliah Bahasa Indonenesia Fakultas Pertanian Universitas Brawijaya Malang, salah satu tujuan pembelajarannya adalah “Mampu mengaplikasikan berbagai model ragam bahasa" dengan materi pembelajaran "Pemahaman filosofi think agriculture". Untuk membentuk pemahaman tentang agrikultur tersebut bisa dilakukan dengan media dongeng. Sebagaimana dikatakan Nunan dalam Saddhono dan Slamet (2012) bahwa dalam pembelajaran bahasa, media dapat dijadikan sebagai saluran yang memberikan stimulan untuk berkomunikasi. Melalui dongeng, dosen dapat menyalurkan pesan yang mampu merangsang pikiran, membangkitkan semangat, perhatian, dan kemauan pembelajar agar terjadi proses pembelajaran pada diri pembelajar.

Dongeng merupakan kerangka cerita yang menggunakan bahasa yang menyenangkan. Cerita tersebut hidup di dalam diri pembaca dan terasa menyenangkan. Mempelajari dongeng berarti mempelajari banyak hal seperti mitos, literasi, kekerasan, psikologi, kelas, ilustrasi, kepengarangan, ekologi, dan gender (Bernheimer, 2009).
Dari segi isinya, dongeng merupakan cerita fantasi sederhana yang peristiwanya tidak benar-benar terjadi. Dongeng tersebut berfungsi untuk mendidik atau menyampaikan ajaran moral dan juga menghibur. Dengan kata lain, dongeng merupakan suatu bentuk karya sastra yang bersifat fiktif karena ceritanya tidak benar-benar terjadi (Triyanto, 2007). Dalam pembelajaran, dongeng bisa dijadikan media untuk mendorong pemikiran kreatif, menemukan solusi baru dari suatu permasalahan, menerima kehidupan seseorang, serta membangun harapan untuk masa depan (Biechonski, 2004).

Dari pengertian tersebut dapat dilihat bahwa dongeng sebagai media setidaknya memiliki dua komponen dasar yaitu pengetahuan dan keterampilan. Kedua komponen tersebut berkaitan dengan hubungan tiga aspek yaitu antara khalayak, produsen, dan media (Rosenbaum dkk dalam Suwarto, 2018). Martens dalam Suwarto (2018) mengaitkan dengan empat aspek yaitu industri, pesan, khalayak,dan efek media.Meskipun berbeda pengelompokan, kedua pakar tersebut mempunyai pandangan yang sama tentang elemendasar literasi media, yakni (a) media dikonstruksikan, (b) pesan yang sama bisa dipersepsikan secara berbeda, dan (c) media berpengaruh terhadap khalayak.

Dengan menggunakan media, penutur berusaha melindungi sekaligus memberdayakan khalayak. Sebagaimana dikatakan oleh Livingstone dalam Suwarto 
(2018) bahwa program literasi media seringkali dimaksudkan untuk meningkatkan (a) demokrasi, partisipasi, dan kewarganegaraan aktif, (b) pengetahuan akan ekonomi, daya saing, dan keragaman pilihan, serta (c) belajar sepanjang hayat, ekspresi budaya, dan pemenuhan pribadi. Melalui media dongeng, pendidik membentuk imajinasi melalui praktik internalisasi budaya agraris yang selanjutnya akan dieksternalisasi pembelajar dalam partisipasi aktif dalam suatu komunitas.

Penelitian ini difokus pada menggunaan dongeng sebagai media pembentuk agriliterasi yang meliputi imajinasi tentang (a) pesan yang sama bisa dipersepsikan secara berbedadan (b) media berperan terhadap khalayak.

\section{METODE PENELITIAN}

Jenis penelitian ini adalah kualitatif deskriptif karena data yang dianalisis dalam bentuk kata-kata atau ucapan dan perilaku yang dapat diamati. Penelitian ini dilakukan untuk mendeskripsikan fenomena-fenomena yang bisa berupa bentuk, aktivitas, karakteristik, perubahan, hubungan, kesamaan, serta perbedaan yang berbeda antara yang satu dengan yang lain.

Metode penelitian yang digunakan adalah analisis isi kualitatif karena yang diteliti dapat berupa teks, gambar, simbol, dan sebagainya untuk memperoleh pemahaman tentang nilai-nilai luhur bangsa Indonesia yang terepresentasi dalam dongeng. Digunakannya analisis isi karena sifatnya yang non-reaktif sehingga terhindar dari sifat subjektif yang direkayasa. Dalam analisis isi ini, dongeng ditempatkan sebagai dokumen untuk memahami makna, signifikansi, dan relevansi nilai-nilai luhur yang akan ditanamkan kepada pembelajar sebagai hasil inferensi-inferensi yang dapat ditiru (replicable) dan sahih sesuai dengan konteksnya.

Sumber data penelitian ini adalah dongeng "Dewi Sri". Adapun data penelitian ini berupa kata-kata dan perilaku yang merepresentasikan (1) pesan dongeng "Dewi Sri" sebagai pembangkit imajinasi agriliterasi dan (2) peran dongeng "Dewi Sri" sebagai pembangkit imajinasi agriliterasi.

Teknik pengumpulan data yang digunakan adalah teknik dokumentasi, observasi, dan studi pustaka. Data yang terkumpul dianalisis melalui tahap deskripsi untuk menganalisis teks dongeng, tahap interpretasi untuk menganalisis proses pembangkitan imajinasi budaya agraris, dan tahap eksplanasi untuk menganalisis budaya agraris sebagai nilai-nilai luhur bangsa.

\section{PEMBAHASAN}

A. Pesan Dongeng "Dewi Sri" sebagai Pembangkit Imajinasi Agriliterasi

Pesan yang disampaikan dalam dongeng "Dewi Sri"merupakan media pembentuk imajinasi mahasiswa agar dapat merangsang pikiran, membangkitkan semangat, perhatian, dan kemauan pembelajar sehingga mereka mampu mempertanggungjawabkan budaya 
agrarisnya. Pesan tersebut menjadi pembangkit keinginan, minat, dan motivasi mahasiswa untuk belajar dan mendalami masalah pertanian sehingga terbentuk mitos yang mampu membangkitkan keinginan mahasiswa untuk memahami pengetahuan dasar tentang pertanian sebagaimana dapat dilihat pada data berikut.

(1) Dahulu kala, hidup seorang penguasa tertinggi kerajaan langit bernama Batara Guru. Suatu hari ia memerintahkan para dewa dan dewi untuk melakukan kerja bakti guna membangun sebuah istana baru yang lebih megah di Kahyangan. la pun mengancam akan memotong tangan dan kaki siapa saja yang malas mengerjakan perintahnya.

Dari data di atas dapat dilihat praktik penanaman budaya agraris yang bernilai tinggi karena bersumber dari kehidupan para dewa. Melalui ujaran "Suatu hari ia memerintahkan para dewa dan dewi untuk melakukan kerja bakti guna membangun sebuah istana baru yang lebih megah di Kahyangan" dikonstruk pesan tentang sistem kerja bakti yang menjadi nilai unggul masyarakat agraris. Pentingnya nilai kerja bakti dapat dilihat dari dongeng yang menunjukkan bahwa kerja bakti dikendalikan langsung oleh Batara Guru sebagai penguasa tertinggi. Dalam dunia agraris ditanamkan nilai bahwa seberat apapun pekerjaan harus dilakukan secara tolong menolong. Sebagai nilai unggul, kerja bakti harus dilakukan secara bertanggung jawab oleh semua anggota masyarakat.Jika tidak menjalankan kerja bakti, masyarakat akan mendapakan sanksi sosial maupun sanksi hukum.

Kerja bakti sebagai bentuk gotong royong merupakan budaya khas masyarakat agraris yang berarti bekerja bersama-sama untuk mengerjakan dan menyelesaikan suatu hasil. Gotong royong merupakan bentuk nilai moral yang tinggi yakni ikhlas dalam berpartipasi dan bekerjasama serta saling membantu antarsesama. Gotong royong dilakukan oleh para petani dalam berbagai aktivitas pertanian, membuat dan memperbaiki rumah dan sekitarnya, pesta, dan peristiwa bencana atau kematian. Gotong royong diistilahkan dengan kerja bakti ketika kegiatan dilakukan terhadap fasilitas umum, baik yang terjadi atas inisiatif warga ataupun dipaksakan oleh pemuka masyarakat.

Pesan lain yang disampaikan melalui dongeng "Dewi Sri" yaitu masyarakat agraris selalu berusaha memahami sesama. Mereka adalah masyarakat yang tanggap secara emosional, sosial, atau fisik sebagaimana dapat dilihat pada data berikut.

(2) Sesampainya di kediaman milik Batara Narada, ia menyampaikan tentang apa yang membuatnya risau. Mendengar curahan hati Antaboga, Batara Narada justru kebingungan dan tidak memiliki solusi. Kemudian Antaboga menangis meratapi nasib buruk yang harus menimpa dirinya.Tak disangka, tetesan air matanya berubah menjadi telur dengan 
kulit yang sangat indah. Melihat keajaiban itu, Barata Narada menyarankan agar telur tersebut diberikan sebagai permohonan maaf karena tidak bisa membantu membangun istana. Tanpa pikir panjang, ia pun bergegas menaruh telur tersebut ke dalam mulutnya dan pergi menemui Batara Guru.

Dari data di atas dapat dilihat bahwa masyarakat agraris merupakan masyarakat yang mempunyai kemampuan menghubungkan keadaan mental diri sendiri dan orang lain. Mereka berusaha memahami orang lain dan mempunyai kepercayaan bahwa orang lain mempunyai kepercayaan, keinginan, dan intensi tersendiri yang bisa jadi berbeda dengan diri kita. Karena itu, mereka akan merasa risau jika tidak bisa bekerjasama untuk membantu sesama. Mereka berusaha keras agar dapat bekerjasama dengan masyarakat.Ketika kondisi tidak memungkinkan untuk berpartisipasi dalam kegiatan masyarakat, mereka berusaha mengganti ketidakhadirannya dengan imbalan yang sebanding dengan kegiatan bersama.Melalui ujaran Barata Narada menyarankan agar telur tersebut diberikan sebagai permohonan maaf karena tidak bisa membantu membangun istanadapat dilihat keadaan mental masyarakat agraris yang merasa bersalah ketika tidak bisa membantu orang lain. Ketika melakukan kesalahan, mereka harus mau minta maaf dengan cara apapun, termasuk dengan memberi sesuatu yang berharga sebagai kompensasi.

Dekatnya hubungan mental antara diri sendiri dan orang lain tersebut merupakan untuk menyatukan pemahaman diri sendiri dan orang lain sehingga tidak terjadi kesalahan maupun salah paham. Hal itu karena mereka mempunyai keyakinan bahwa kesalahan yang dilakukan seseorang dapat menyebabkan terjadinya bencana di lingkungan tingal mereka. Karena itu, ketika ada anggota masyarakat yang melanggar norma, mereka berusaha menghentikannya sebagaimana dapat dilihat pada data berikut.

(3) Dikisahkan bahwa Batara Guru lama-kelamaan menyukai Nyi Pohaci Sanghyang Sri dan hendak memperistrinya. Para dewa di Khayangan merasa resah dengan hal ini, takut menghadirkan bencana di Khayangan. Akhirnya mereka berencana memisahkan Batara Guru dari Nyi Pohaci Sanghyang Sri dengan menaruh racun pada minuman Nyi Pohaci Sanghyang Sri hingga akhirnya meninggal. Untuk menghilangkan jejak perbuatan keji mereka, jenazah Nyi Pohaci Sanghyang Sri dibawa turun ke bumi dan dikubur di tempat tersembunyi.

Dari data di atas dapat dilihat bahwa karakter masyarakat agraris yang peduli terhadap sesama. Mereka memperhatikan semua perilaku masyarakat sekitar baik yang benar maupun yang salah. Mereka tidakakan membiarkan seseorang melakukan 
kesalahan.Mereka meyakini bahwa kesalahan yang dilakukan seseorang dapat menimbulkan bencana bagi lingkungan. Melalui ujaran akhirnya mereka berencana memisahkan Batara Guru dari Nyi Pohaci Sanghyang Sri dengan menaruh racun pada minuman Nyi Pohaci Sanghyang Sri hingga akhirnya meninggal dapat dilihat kepedulian masyarakat agraris terhadap lingkungan tinggal mereka. Mereka tidak mau lingkungannya rusak karena perbuatan keji dari salah satu warganya.Bahkan, mereka tidak segan untuk menghilangkan nyawa seseorang yang baik demi kelestarian lingkungan.Akan tetapi dalam masyarakat agraris, masyarakat yang lemah sering dikurbankan.

Akan tetapi eratnya hubungan mental mereka membuat mereka bersalah ketika melakukan perbuatan tidak baik kepada orang lain. Dengan menggunakan ujaran untuk menghilangkan jejak perbuatan keji mereka, jenazah Nyi Pohaci Sanghyang Sri dibawa turun ke bumi dan dikubur di tempat tersembunyi,dapat dilihat pesan moral masyarakat yang takut jika kesalahannya diketahui orang lain. Meskipun perbuatan mereka dilakukan untuk kebaikan, mereka tetap merasa takut jika perbuatannya diketahui orang lain. Mereka berusaha untuk menyembunyikan kesalahannya karena mereka tidak mau menyakiti hati orang lain.

Untuk menjaga kebaikannya, dalam dongeng "Dewi Sri" terepresentasi kayakinan bahwa perbuatan baik akan membuahkan kebaikan. Mereka yakin jika dalam hidupnya seseorang selalu berbuat baik dan bermanfaat bagi sesama, maka ketika sudah meninggal mereka juga akan baik sebagaimana dapat dilihat pada data berikut.

(4) Konon, pusara dari Nyi Pohaci Sanghyang Sri kemudian ditumbuhi tanaman padi yang sangat bermanfaat bagi manusia di bumi. Sejak saat itulah Nyi Pohaci Sanghyang Sri atau dewi Sri dijuluki sebagai dewi Padi.

Dari data tersebut dapat dilihat bahwa semua kebaikan yang dilakukan oleh Dewi Sri bisa dinikmati oleh seluruh manusia ketika dia sudah meninggal. Meskipun menderita karena penindasan dan penganiayaan yang dilakukan oleh Batara Guru dan pembunuhan yang dilakukan oleh pada dewa di kahyangan, Dewi Sri tetap berbuat baik dan menerima kesengsaraan yang terjadi pada dirinya dengan rasa syukur dan kerendahan hati.

Selain itu, melalui dongeng "Dewi Sri" juga ditanamkan nilai bahwa tumbuhtumbuhan yang bisa dimaknai dengan sumber kehidupan berasal dari seorang wanita. Melalui dongeng ini juga ditanamkan praktik pemujaan terhadap kesuburan, yang menjadi inti dari kebudayaan agraris di seluruh dunia yang bersifat turun menurun.

Pesan dari dongeng "Dewi Sri" adalah Dewi Sri merupakan personifikasi dari tanah yang "melahirkan" tanam-tanaman yang dibutuhkan oleh manusia. Pada masa bercocok tanam, masyarakat tradisional sering melakukan pemujaan terhadap Dewi Sri yang sering kali dipuja 
bersama dengan pasangannya, pria. Dalam upacara tersebut, lingga (lambang alat kelamin pria) dan yoni (lambang alat kelamin wanita) berjalan beriringan. Hal itu karena prinsipnya persatuan keduanya melambangkan kehidupan.

Melalui dongeng "Dewi Sri" tersebut, dosen diharapkan dapat mengkonstruk pengetahuan akan budaya lokal agraris dengan adat istiadat daerah melalui cara yang menghibur. Agar bisa dilaksanakan dengan baik, interaksi dalam mendongeng bisa dilakukan dengan membiarkan mahasiswa ikut terlibat dalam kegiatan mendongeng. Mereka bisa berpartisipasi dalam melanjutkan cerita dan peristiwa yang dialami para tokoh cerita. Dengan cara tersebut, mahasiswa bisa dikembangkan kemampuan berpikirnya dan dapat mengutarakan pendapat dengan bebas tapi terarah. Dengan begitu, dalam diri mahasiswa akan terbentuk integritas dan rasa syukur. Selanjutnya mereka akan menjadi manusia yang selalu meningkatkan rasa syukur terhadap semua yang telah Allah takdirkan kepada mereka.

\section{B. Peran Dongeng "Dewi Sri" sebagai} Pembangkit Imajinasi Agriliterasi Mahasiswa

Indonesia merupakan negara agraris.Akan tetapi, pengaruh globalisasi menyebabkan terjadinya penurunan perhatian pemerintah dan masyarakat terhadap pertanian.Untuk meningkatkan perhatian masyarakat, khususnya generasi muda, terhadap pertanian, mereka perlu dikenalkan kembali budaya asli mereka.Salah satunya adalah melalui dongeng "Dewi Sri" yang dikenal sebagai dewi padi sebagaimana dapat dilihat pada data berikut.

(5) Dialah Antaboga, seorang dewa ular yang merasa cemas dengan ancaman yang dibuat oleh Batara Guru. Mengetahui kondisi tubuhnya yang tidak memiliki tangan dan kaki, tentu ia akan merasa kesulitan untuk bekerja. Namun, jika ia tidak bekerja, lehernya akan dipenggal.

Dari data di atas dapat dilihat peran dongeng "Dewi Sri" sebagai sarana pembentuk empati mahasiswa terhadap budaya agraris.Dengan menghadirkan tokoh-tokoh dewa seperti Antaboga dan Batara Gurudilakukan praktik internalisasi rasa bangga terhadap masyarakat agraris yang merupakan keturunan para dewa. Selain itu, melalui tokoh Antaboga juga diinternalisasi sikap bangga terhadap masyarakat agraris yang bertanggung jawab terhadap keadaan yang menimpa dirinya.Mereka tidak mudah menyalahkan orang lain.

Dengan sikap empati yang dimiliki diharapkan agar mahasiswa dapat menjaga ekosistem sehingga tidak terjadi eksploitasi lahan pertanian. Mereka akan menjaga lahan sebagaimana mereka menjaga leluhurnya. Dalam melakukan budidaya pertanian, mereka tidak hanya memanfaatkan dan tidak pula mengeksploitasi lahan semau-maunya. Mereka diharapkan akan selalu mempedulikan dampak-dampak dari 
budidaya yang mungkin akan terjadi jika mereka hanya eksploitasi lahan secara berlebihan.

Melalui dongeng "Dewi Sri" juga ditanamkan mental pejuang yang tidak kenal menyerah meski sampai berurai air mata sebagaimana dapat dilihat pada data berikut.

(6) Diceritakan bahwa dalam tangisnya ada sesuatu hal yang terjadi yaitu tiga tetes air matanya berubah menjadi mustika berupa telur dengan kulit yang indah dan juga bersinar. Akhirnya Barata Narada menyarankan supaya mustika-mustika tersebut dijadikan persembahan ke Batara Guru sebagai permohonan karena tidak bisa membantu untuk membangun istana. Singkat cerita ia pun segera membawa telur tersebut dimulutnya.

Dari data di atas dapat dilihat peran dongeng Dewi Sri dalam menanamkan semangat juang. Melalui ujaran dalam tangisnya ada sesuatu hal yang terjadi yaitu tiga tetes air matanya berubah menjadi mustika berupa telur dengan kulit yang indah dan juga bersinar dapat dilakukan proses internalisasi semangat juang untuk mendapatkan hasil maksimal. Dalam diri mahasiswa dibentuk keyakinan bahwa dalam setiap usaha selaluada hasil yang sebanding. Setiap ada persoalan, mereka harus mencari jalan keluar untuk mengatasi persoalannya. Kalau semua usaha sudah dilakukan mereka harus berdoa.Selanjutnya, mereka boleh pasrah dan menerima takdir karena rizki manusia ditentukan oleh Allah yang maha kuasa.Dari data yang menunjukkan perubahan dari tetesan air mata menjadi mustika dapat diinternalisasi adanya balasan yang sebanding dengan perjuangan.

Selain itu, melalui dongeng "Dewi Sri" juga dapat diinternalisasi sikap menjaga keselarasan lingkungan sebagaimana dapat dilihat pada data berikut.

(7) Dikisahkan bahwa Batara Guru sang ayah angkat rupanya ingin memperistri Nyi Pohaci hingga membuat para dewa di kahyangan menjadi khawatir karena hal tersebut bisa merusak keselarasan di kahyangan. Mereka akhirnya berencana memisahkan Batara Guru dan Nyi Pohaci Sanghyang Sri dengan menaruh racun pada minuman Nyi Pohaci Sanghyang Sri hingga akhirnya meninggal. Agar tidak diketahui jejaknya akhirnya jenazah Nyi Pohacipun dibawa turun ke bumi dan dikuburkan ditempat yang jauh juga tersembunyi.

Dari data di atas dapat dilihat praktik internalisasi sikap menjaga keselarasan lingkungan. Agar lingkungan terjaga, mereka tidak boleh bersikap apatis terhadap sesama.Ketika ada pihak yang melakukan kesalahan, mereka harus berusaha untuk mencegahnya. Melalui data di atas dapat dilihat usaha para dewa untuk menjaga keselarasan kahyangan dengan mencegah terjadinya perbuatan keji Batara Guru yang ingin memperistri Dewi Sri, meskipun harus ada yang dikurbankan. Dengan cara tersebut dapat 
diinternalisasi sikap rela berkorban demi menjaga lingkungan. Pengurbanan Dewi Sri tersebutmelambangkan pengurbanan petani yang harus menyebar biji tanaman untuk mendapatkan tumbuhan baru. Selain itu, biji tanaman juga harus rela hancur terlebih dahulu demi mendapatkan biji-biji baru yang jumlahnya lebih banyak.

Dari data di atas dapat dilihat bahwa dongeng "Dewi Sri" merupakan media untuk meningkatkan kemampuan literasi ekologi pada diri mahasiswa. Literasi tersebut merupakan kemampuan kognitif yang dilengkapi dengan perilaku empati terhadap semua bentuk kehidupan. Kemampuan kognitif mahasiswa yang bisa ditingkatkan melalui dongeng Dewi Sri ini adalah kemampuan memahami ilmu tentang nilai, sikap, dan perilaku masyarakat budaya agraris. Selanjutnya, mahasiswa dibimbing untuk bersikap empati terhadap semua bentuk kehidupan yang terjadi pada masyarakat agraris. Selanjutnya, mereka akan termotivasi untuk mencintai dan bersama-sama memelihara budaya agraris.

Selain itu, literasi budaya tersebut juga bersifat kolektif.Mereka perlu melakukan tindakan bersama untuk menghasilkan dampak positif bagi kelangsungan ekologi.Sebagaimana dapat dilihat pada ujaran mereka akhirnya berencana memisahkan Batara Guru dan Nyi Pohaci Sanghyang Sri dengan menaruh racun pada minuman $\mathrm{Nyi}$ Pohaci Sanghyang Sri hingga akhirnya meninggal, yang menunjukkan bahwa untuk menyelesaikan persoalan lingkungan harus direncanakan dan dilakukan bersama-sama. Sifat kolektif sebagai keterampilan sosial tersebut dibutuhkan sebagai perekat keharmonisan hidup manusia dengan sesama dan alam yang menjadi tempat hidup dan kehidupan.

Dengan dongeng "Dewi Sri" tersebut, dosen dapat menanamkan nilai dengan cara yang ramah dan menyenangkan sebagai upaya untuk memberikan pengasuhan positif. Agar sesuai dengan usia mahasiswa, kegiatan mendongeng dilakukan dengan memodifikasi proses mendongeng baik dengan jalan mengubah konten maupun teknik mendongeng. Dengan modifikasi tersebut diharapkan agar dongeng dapat dipahami anak secara komunikatif dan aktif.Selain itu, modifikasi juga digunakan untuk menghindari indoktrinasi. Sebagaimana dapat dikatakan Ahyani (2010) bahwa modifikasi dongeng merupakan proses pelibatan partisipasi bernalar sesuai dengan karakter anak sebagai salah satu variasi pembelajaran untuk mengaktifasi fungsi penalaran anak.

\section{PENUTUP}

Berdasarkan hasil analisis di atas dapat disimpulkan sebagai berikut.Pesan dongeng "Dewi Sri" adalah tanah merupakan ibu yang "melahirkan" tanamtanaman yang dibutuhkan oleh manusia. Mahasiswa sebagai anggota masyarakat agraris harus menghargai tanah sesuai dengan budaya agrarisnya. Melalui cara 
tersebut, dalam diri mahasiswa harus terbentuk integritas dan rasa syukur.

Peran dongeng "Dewi Sri"adalah sebagai media untuk meningkatkan kemampuan literasi ekologi yang bersifat kolektif pada diri mahasiswa. Sifat kolektif dibutuhkan sebagai perekat keharmonisan hidup manusia dengan sesama dan alam yang menjadi tempat hidup dan kehidupan. Melalui dongeng dapat ditanamkan nilai secara ramah dan menyenangkan sehingga terjadi pengasuhan positif.

\section{B. Saran}

Berdasarkan hasil penelitian di atas dapat dirumuskan saran sebagai berikut.Kepada para dosen diharapkan dapat memanfaatkan dongeng "Dewi Sri" sebagai media pembelajaran yang menyenangkan dalam rangka membentuk pembelajar menjadi subjek agraris (agriliterasi). Kepada anggota masyarakat diharapkan dapat memanfaatkan dongeng "Dewi Sri" sebagai media pengikat rasa persatuan agar semakin bijak dalam menghadapi perkembangan dunia industri yang menjadi tantangan dunia agraris. Kepada peneliti selanjutnya diharapkan dapat melakukan penelitian dengan berbagai pendekatan historis etnografis sehingga dapat memperoleh konstruk teori tentang strategi peningkatan kemampuan agriliterasiberbasis muatan lokal.

\section{DAFTAR PUSTAKA}

Ahyani, L. N. (2010). Metode Mendongeng dalam Meningkatkan Perkembangan Kecerdasan Moral Anak Usia Pra Sekolah dalam Jurnal Psikologi Universitas Muria Kudus, Vol. 1 , No. 1. http://journal.umk.ac.id/index.php/ip sikolog/article/viewFile/201/210.

Diunduh 12 Januari 2016. Pukul 20.59. Bernheimer, K. (2009). Fairy Tale is Form, Form is Fairy Talein The Writer's Notebook: Craft Essays from Tin House. Tin House.http://www.katebernheimer.c om/images/Fairy\%20Tale\%20is\%20Fo rm.pdf. Diunduh tanggal 31 Desember 2018.Pukul 20.50.

Kusumadewi, L. R. (2017). Model Literasi yang Bermanfaat untuk Indonesia: Bukan Sekadar Melek Huruf. http://theconversation.com/modelliterasi-yang-bermanfaat-untukindonesia-bukan-sekadar-melekhuruf-82508. Diunduh tanggal 13 Januari 2019. Pukul 17.33

Mahligai Indonesia. (2017). Legenda Dewi Sri, Dewi Kesuburan di Muka Bumi.http://mahligaiindonesia.com/ragam-budaya/tradisinusantara/legenda-dewi-sri-dewikesuburan-di-muka-bumi-5961.

Diunduh tanggal 12 januari 2019.Pukul 22.12.

Rick, D.S. (2002). Learning about Livelihoods: Insights from Southern Africa. United Kingdom: Oxvam GB. https://oxfamilibrary.openrepository. com/bitstream/handle/10546/12108 
0/bk-learning-about-livelihoods-

$\underline{010802-}$

en. pdf;jsessionid $=8 D F 23 D 564 F 03 B B 6$

471CB01162E942E5F? sequence $=1$.

Diunduh tanggal 16 Januari 2019.

Pukul 08.21

Saddhono, K \& Slamet, St. Y. (2012).

Meningkatkan Keterampilan

Berbahasa Indonesia. Bandung: Karya

Putra Darwati.

Suwarto, D. H. (2018). Gerakan Literasi

Media di Indonesia.

file:///C:/Users/WINDOWS\%208.1/D

ownloads/BukuGerakanLiterasi.pdf

diunduh tanggal 31 Desember 2018.Pukul 20.35.

Triyanto, A. (2007). Pembahasan Tuntas Kompetesi Bahasa Indonesia untuk SMP dan MTs kelas VII. Jakarta: Esis.

Oxenham, J; Diallo, A.H.; Katahoire, A.R. \& Sall, O. (2002). Skills and Literacy Training for Better Livelihoods: A Review of Approaches and Experiences.

http://siteresources.worldbank.org/A FRICAEXT/Resources/skills and litera cy.pdf. Diunduh tanggal 16 Januari 2019. Pukul 08.31 